\title{
Otherness AND IDENTIty in TABu From Miguel Gomes
}

\author{
Ana Cristina Pereira
}

\begin{abstract}
Portuguese national identity has been constructed over time, across various media, including the cinema, in contrast to the identity of an African "other", who is simultaneously close and distant, an heir and a challenger, an object of seduction and repulsion. These dualities are reflected in Miguel Gomes' Tabu (2012), which reifies and questions various representations. It is a postcolonial film which reflects about the way how stereotypes and social and "racial" representations created during colonialism have repercussions on present-day Portuguese society. The film offers a critical vision of a certain Portuguese elite in Africa and the manner in which this elite experienced the War for Independence, confronting this period in Portuguese history with the present day. The director's filmic discourse is analysed using a multimodal semiotic approach: an analysis of Tabu, taking into account the processes of categorisation, either in terms of inclusion or exclusion. The texts present a dialogic interpretation of semiotic resources, such as rhythm, composition, informal linking and dialogues. The goal of this multimodal analysis is to understand the representation of the African "other" in the film and how Portuguese identity is constructed in the relationship to this other.
\end{abstract}

\section{Keywords}

Tabu film; "racial" representations; otherness; identity; multimodal semiotics

\section{INTRODUCTION}

Tabu (2012), directed by Miguel Gomes, presents a construction of Portuguese identity based on the country's relationship with Africa. The film may be interpreted as a critical reflection about the presence of dynamics created during colonialism in presentday Portuguese society. However this interpretation is open to debate, to the extent that the film questions several stereotypes, while seeming to want to emphasise others.

An analysis of Tabu is proposed herein, that takes into account processes of categorisation via inclusion and exclusion. Several sequences will be analysed in detail, presenting a dialogic reading of semiotic resources, such as rhythm, composition, informal connections and dialogues. This multimodal analysis (van Leeuwen, 2005) aims to understand the way that the film portrays the African "other" and how Portuguese identity is constructed in relation to this other.

Identity and otherness are neither natural nor intrinsic qualities of individuals; they are transformed by culture because they form part of it, and they are thought of in this regard as fluid and mobile constructions, and above all not as qualities created in a necessarily innocent manner, nor as unconscious appropriations (Pereira \& Cabecinhas, 2014). Recent studies (Piçarra, 2015) show that over in the history of cinema, film has been an important medium for the construction and reconstruction of identities and alterities, and that films are influenced by the historical epoch in which they are produced. 
Postcolonial critique questions the historical process of European colonisation and produces readings that try to deconstruct the colonialist discourse at different levels: in literature, art, science, philosophy, politics, justice, religion, among others. These studies emphasise the way that the colonised populations were represented during the colonial era, while intending to "identify to what extent colonialism is present as a social relation in colonising societies of the north, although ideologically concealed by the description that the latter make of themselves" (Santos, 2004, p. 23). Thus, colonialism as a field of study is more like a lens that is used to observe reality than a specific area of work.

Just as post colonialism in general is not a fixed condition, nor specific to a certain epoch or place, postcolonial cinema cannot be defined as a genre or category (Ponzanesi $\&$ Waller, 2012). Hence, we can understand postcolonial cinema as a relatively vast (and diversified) set of films, which embraces the concern to reflect about the characteristics and consequences of colonialism and decolonisation on people and societies.

This article begins with a brief presentation of the proposal of multimodal analysis made by Theo van Leeuwen (2005), which underpins the reflection of Tabu, notwithstanding the importance of other contributions. The second part of the article analyses the film itself, in view of the relationship between identity and otherness, conceptions of cinema, and the aforementioned postcolonial studies.

This is therefore a work based on a postcolonial lens. This condition enables us to observe a critical intension of colonialism in the film in question.

\section{Proposed Theoretical AND PRACTICAL ANALYSis}

Any discursive construction receives various contributions, whether from the press, art, academic research, or other sources that are sometimes difficult to identify, from where it may be concluded that discourses have a social distribution and may be activated in different manners: actions, lifestyles, attitudes, amongst others (van Leeuwen, 2005 , p. 98). The multimodal analysis proposed by van Leeuwen (2005) is a form of social semiotic analysis that aims to establish a theoretical and practical approach to different means of communication simultaneously: image, text, oral speech, objects, etc. In multimodal analysis of a communicational event, such as a film, the elements or groups of elements to be analysed are: rhythm, composition, informal linking and the dialogues. These elements are analysed separately although they operate jointly.

\section{RHYTHM AND COMPOSITION}

Rhythm offers coherence and a structure of meaning to communicational events that unfold over time, and thus represent a crucial element in any film. In turn, composition offers coherence and a structure of meaning to spatial arrangements. Rhythm and composition are sources of cohesion in multimodal texts. Rhythm is related to time. It results from the alternation between slow and fast movements, from the duration of the dialogues and the shots, and management of the silences. Composition is related to 
space, i.e. the layout. Rhythm acts on events with a temporal duration: conversations, music, action, dance, amongst others, whereas layout offers coherence in spatially organised texts: pages, canvases, frames, museum exhibitions, etc. In films we have a permanent combination of both elements, given that the action, dialogues, etc. unfold over time but are spatially organised and reflected on a screen.

Rhythm is essential to merge the various meanings expressed via the different semiotic modes encompassed within the multimodal composition of a film: action, dialogues, music and other sounds. The essence of rhythm is alternation: high/low; day/ night; rough/soft; fast/slow, etc. This kind of alternation, according to the author, is so vital for the humans, that we can perceive it, even without being there (van Leeuwen, 2005, pp. 181-198).

Analysis of composition is to understand how elements are distributed in space, whether they are people, things, forms of nature, or abstract forms. It is this space that is reflected on the screen. This distribution, although it may be achieved using a concept of primary equilibrium in human beings, obviously has a semiotic reading. For example: placing something in the centre, placing something else to the right, and another of similar weight to the left, is a balanced construction that has a reading. The elements of a page are laid out in function of their weight and, we could say, according to the importance that we want to assign them. In the case of cinema we have a third dimension and therefore it's not a question of whether the elements are placed top or bottom, left or right, in the centre or at the margins, but also, and very importantly, in the foreground or background, nearby or far away (van Leeuwen, 2005, pp. 198-219).

\section{INFORMAL LINKING}

Informal linking mean the cognitive links between different elements of information in time and/or space, for example, temporal or casual links between images and words in multimodal texts. The information often only makes sense within a certain context: "information can only be interpreted in the context of other pieces of information and of specific communicative interests and purposes" (van Leeuwen, 2005, pp. 219). The links between pieces of information have not only cumulative value but also cognitive value: "They connect information in terms of such cognitive categories, as causal or temporal relationships, and it is these categories that make the items of information meaningful in relation to each other" (van Leeuwen, 2005, p. 219). There are logical or obvious links that are made by conjunctions such as: then, next, the day after, etc. There are also additional links that add an idea (information) without warning: but, on the other hand. In cinema temporal links are the main form of conjunction, because in film time is not linear. There are flashbacks and flash-forwards and also actions that occur simultaneously. The montage may allow material to appear in the film which although it isn't directly part of the story, helps us interpret the story. For this purpose, logical links of contrast or similarity have been created (van Leeuwen, 2005, pp. 220-248). 


\section{DiALOgues}

Multimodal cohesion may also be seen through the dynamic interconnection of dialogues, understood here as structures of dialogue-based exchanges with the forms of musical interaction. The logic of the dialogue is parallel and independent of the semantic logic. The dialogues coexist and do not prejudice each other, since individuals have the ability to cope with both simultaneously, and in different registers and functions, although the latter may be complementary (van Leeuwen, 2005, p. 248). The principal characteristic of the dialogues is that they are sequentially multimodal. Every action causes another action, subsequently and simultaneously, because at the same time that one action occurs, (one dialogue) other actions also occur.

\section{Critical ANALYSis OF THE Discourses}

Theo van Leeuwen's concept of discourse (2005), is based on the work of Foucault (1997), and defines discourses as socially constructed forms of knowledge concerning a specific aspect of reality. The author explains that the term "socially constructed" means that these forms of knowledge have been developed in specific social contexts and in order to serve interests of specific social actors of these specific contexts (2005, p. 94). Hence the discourses are resources of representation of some aspect of reality that are activated when that particular aspect of reality is represented. The discourses do not determine how we can represent any specific aspect of reality, although we cannot say anything without them. We need discourses as frameworks to give sense to things $(2005$, p. 95). In addition, discourses are always plural. There may be several discourses concerning the same aspect of reality, wherein they all include and exclude different things, in function of the contexts that originated them (2005, p. 95).

Evidence of the existence of a certain discourse may be found in the texts, in what has been said, written or expressed by other semiotic means. More specifically, a discourse results from the resemblance between things that were expressed, in different texts, concerning the same aspect of reality. It's on the basis of the similarity between declarations, that are repeated or paraphrased in different texts and distributed across these texts in different forms, that we can rebuild the discourse concerning a specific aspect of reality and understand the specific knowledge that this discourse represents (van Leeuwen, 2005, p. 95; 2008, p. 98).

Critical analysis of the discourse questions the language, understanding it as a social practice that is therefore socially determined and restricted, at the same time that it produces effects on society and transforms it. Thus, in the perspective of this practice of analysis, language and society are simultaneously generators of, and dependent upon, each other. Language isn't just a reflection of social structures but an intrinsic part of them, and is therefore a complex phenomenon, a non-transparent process of social production and interaction, that combines social subjects, objects and society (Fairclough, 2001, pp. 130-131).

Representations, in certain contexts, exclude social actors and are ideological because they help to maintain and disseminate relations of domination within a specific 
practice. Van Leeuwen $(1997,2008)$ seeks to understand the relation between social actors and their socio-cultural context, to clarify the manner in which individuals are included or excluded in the discourse, given that, since they are socially constructed, representations can also be deconstructed.

\section{REPRESENTATIONS IN THE LANGUAGE}

By conducting a "socio-semantic inventory" used to identify and classify the many forms of representing social actors, Theo van Leeuwen $(1997,2008)$ highlights that "agency, for instance, as sociological concept, is of major and classic importance in critical discourse analysis: in which contexts are which social actors represented as 'agents' and which as 'patients'?" (2008, p. 2). In this manner, the author inventoried the ways in which social actors can be represented, in what can be called a socio-discursive inventory, and established the sociological and critical relevance of some linguistic categories. For van Leeuwen these categories are pan-semiotic, since a culture (or a given cultural context) always has its own specific order of forms of representing the social world, and also its own forms of representing the different semiotics and, in this manner, every culture or cultural context may determine, with greater or lesser accuracy, that which can be achieved verbally and visually, that which can only be achieved verbally, and that which can only be achieved visually (van Leeuwen, 1997, p. 171). In this manner, we realise that "meanings belong to culture rather than to language and cannot be tied to any specific semiotic" (van Leeuwen, 2008, p. 24).

The categories of representation of social actors belong to a complex network of different linguistic systems that contemplate, on the one hand, lexical and grammatical aspects and, on the other hand rhetorical figures. These linguistic systems undergo alterations through processes that involve the extinction, restructuring and substitution of linguistic consistency. The processes of exclusion and inclusion are perhaps the most relevant.

According to van Leeuwen, exclusion has operated as an important aspect for comprehension of how social actors are represented in texts, since "representations include or exclude social actors to suit their interests and purposes in relation to the readers for whom they are intended." (van Leeuwen, 2008, p. 28). The exclusion process can occur by suppression, which is a way to exclude, without living any references to social actors anywhere in the text, or to relegate the actions to a second level, when they are not mentioned in relation to a specific activity, but are present in the text.

In relation to the process of inclusion, the author recalls that herein lies the great political strength of representation of social actors, given that, in the discourse, the representations and relations of the social actors suffer a distribution that doesn't necessary reflect the social practice. In other words, there is not always an effective correspondence between the role that the social actors actually play in social practices and the grammatical roles that are assigned to them in the discourse (van Leeuwen, 2008, p. 37).

The inclusion process may involve the actors represented as passive entities or agents, in actions that are often socially undervalued, or in socially deviant behaviour, or 
as subservient persons, criminals or evil people. The actors may also be included, in a specific or generic manner, often by cultural categorisation with a negative connotation or biological categorisation, implying the use of ethnic stereotypes. Finally, social actors may be included as an individual or as a group, in the second case by differentiation or homogenising, which sometimes leads to denial of individual differences and characteristics, and in the attribution of a unique identity (van Leeuwen, 2008).

Stereotypes are necessary for mental organisation of the information, but "if on the one hand, stereotypes are tools that help individuals in simplification, organisation and prediction of the world that would otherwise be excessively complex, on the other hand, stereotypes may have negative consequences in terms of intergroup relations" (Cabecinhas, 2002, p. 410) to the extent that they are abusive simplifications, and sometimes false simplifications, of reality.

\section{AN INTERPRETATION OF TABU}

Structurally divided into a Prologue; Part One (Paradise Lost); and Part Two (Paradise) Tabu; tells, in part one, the story of three women living in present-day Lisbon, and in part two, the past life of one of these women in Africa. This film, directed by Miguel Gomes, was shot in black and white, in 4/3 format, on Kodak film, and most of it is silent, although it has voiceover narration. The film has been often interpreted as a homage to the history of cinema, specifically to some of its foremost directors (Mendes, 2013) and the filmmaker confessed his desire to pay tribute to Friedrich Wilhelm Murnau, amongst other influences.

Miguel Gomes however values the choices made by spectators. In an interview with Elliot Kotek (2012) he points out:

The most important point of view is the point of view of the people who are watching the film. What I try to provide in the film is like a space where you can chose things. There are lots of ambiguous things in the film, and I think that is to give the opportunity to the person who sees it to place and chose, take a position.

Regardless of the intentions expressed by their directors, films are not immune to the time and the social political context in which they are produced and interpreted. Films, like any other communicational event, don't have a unique and intrinsic interpretation that the critic may extract from the work and reveal to the world. On the contrary; the interpretations are multiple (as many as the number of spectators), and they are not necessarily mutually exclusive. On many occasions, the various approaches to a communicational event become complementary.

Critical analysis of a discourse is particularly interesting analytic practise, for the work proposed herein, precisely because it allows this subjective dialogue between the film and the spectator, wherein both form part of the discourse that will be built in relation to reality. As a theoretical practical exercise of analysis, van Leeuwen's multimodal 
approach is particularly seductive because it makes it possible to address artistic objects, in a global manner and place them in dialogue with sociological, political and historical questions.

\section{Prologue}

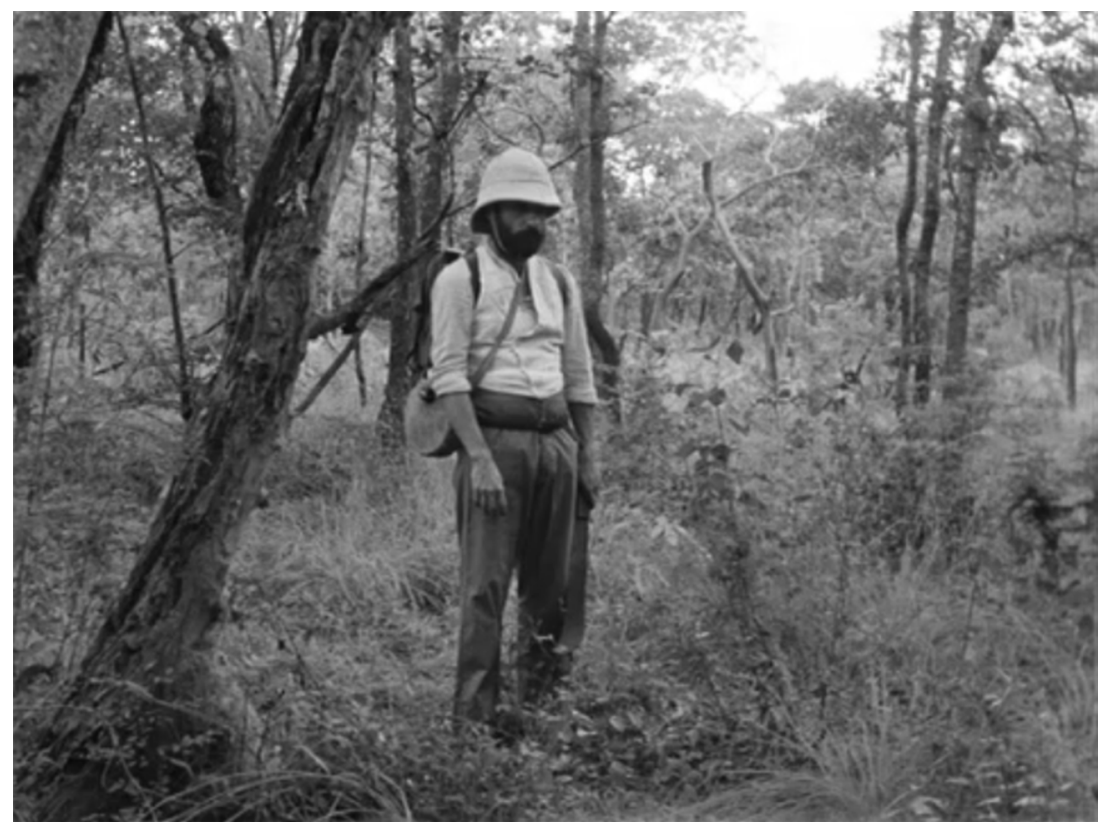

Figure 1: The fearless explorer wandering through the untamed jungle (C) Miguel Gomes

Trusting in the spectator's ability to establish cognitively what van Leeuwen calls informal connections, in this case temporal connections, the film begins with a Prologue, set at the end of the 19th century, when some representations of the Portuguese colonist, and by extension of Portuguese colonialism, were created and defined, thus giving the motto for the reflection that the film subsequently proposes.

In this Prologue we see an explorer wearing a "tropical" hat and a canteen. The shot, the pose and the framing reminds us of colonial photographs of the late $19^{\text {th }}$ century or early $20^{\text {th }}$ century, and in fact, this character standing in the image (and in time) in all components of his discourse, represents the Portuguese colonist as he was initially conceived and subsequently reproduced: protected by law and by divine will and at the service of a humanistic and scientific project, rather than economic interests (Baptista, 2013; Matos, 2006).

The image gains movement when a group of black transporters enter the shot, and move across the image, appearing first from the right moving in direction towards the background and then from the left moving towards the same point, giving the idea of great activity, without ever acquiring protagonism, and without ever highlighting any character. The Africans are categorised, from the outset, as a homogeneous group, which is distinguished by its biological and cultural differentiation in relation to the scene's main protagonist. This is how the black people in Africa are shown throughout the film. This 
succession of opening shots, that seem to reproduce representations of the epoch, reveals the structure of the identity-based construction of the colonist, based on the work and subservience of the colonised peoples, but embellished and disguised by a discourse of high humanitarian and religious values (Ferreira, 2014). This identity-based construction of the colonist would find it difficult to survive without its "flip" side, i.e. the African "other" - wild and lacking the civilising action of the European. The film portrays the way how the subject that is portrayed as "normal", "identical", "the I", "superior" is defined in opposition to the "not normal", "different", "other", "inferior". The idea that the images we have of a certain reality are not innocent, together with the colonialist imaginary universe and its artificiality, run throughout the story told in Tabu. The origin of this imaginary universe is photographic, cinematographic, and literary. "The main reference, however, is the preferred mixture of the dominant cinema, especially of Hollywood, between the love story and adventure" (Ferreira, 2014, p. 286). The colonialist discourse was constructed on various supports and using various texts and semiotic media (literature, photography, cinema, religion, science, etc.) where specific ideas are repeated and complemented that will constitute the constituent body of this discourse or representation (Van Leeuwen, 2005, p. 95) and in this Prologue, Gomes promises to help us to deconstruct this process.

After some wanderings through the jungle, the Explorer, warned by his wife's ghost that he cannot escape from pain, decides to throw himself into the river and dies, eaten by a crocodile. At that moment, the black transporters, who watched everything without intervening or showing any surprise, suddenly begin a traditional dance. Some of them stare directly at the camera as if they were participating in a staged event. The tone and the contour of the narrative, accompanied by a voiceover, makes us think of documentaries, although the text is related to the protagonist's amorous sentiments. Gomes creates a hybrid form, halfway between documentary and fiction. Everything we see is fiction, but the filmmaker mixes filmic construction elements that are traditionally associated to fiction, with others that are normally associated to documentaries. In so doing, he makes us think of documentaries and ethnographic films that were quite "fictionalised" or, in other words, were oriented ideologically', made during the Estado Novo ${ }^{2}$ regime and of fiction films that, also at this time, were the source of imagined and re-created realities. "Film is a privileged media for construction of the perception of reality. In this context, [the Estado Novo regime], film serves to achieve the desire of recording what can be seen, and also what one wants to be seen" (Matos, 2006, p. 94).

Described in this manner, Tabu's Prologue looks like a scene from a burlesque comedy. However, the seriousness with which the characters experience the moment and with which the narrator describes it, makes us think of the style of high comedy, which is characterised by a strong contrast between the ridiculous nature of a specific form of behaviour or action and the seriousness with which is developed or practiced. At the

\footnotetext{
' Amongst others, for example: A Acção Civilizadora dos Portugueses (1932) from António Antunes da Mata, produced by Agência Geral do Ultramar - http://www.cinemateca.pt/Cinemateca-Digital/Video.aspx

${ }^{2}$ New State (Estado Novo) - Portuguese authoritarian political regime, between 1926 and 1974.
} 
end of this initial experience it is difficult to consider that the prevailing discourses, i.e. representations (Van Leeuwen, 2008) concerning colonialism, Africa or the relationship between the Portuguese and the Africans, may be innocent.

The Prologue presents the film, in the sense that it enlightens us about its dual discourses. There is the discourse of the characters who introduce us to part of the common thinking about colonialism and contemporary Portuguese history wherein this thinking was constructed by political propaganda, also in the cinema (Piçarra, 2015). On the other hand, there is the director's discourse in relation to this common sense discourse, based on a critical tradition of colonialism and Euro-centrism, wherein we can highlight the first Tabu, by Friedrich Wilhelm Murnau, made in 1931, which was already a critique of colonialism.

\section{PARAdise LosT}

Leaving the movie theatre - where she has just watched the Prologue, a film inside the film of Tabu - Pilar (Teresa Madruga), "enters" Paradise Lost, the first part of this diptych, which takes place in present-day Lisbon (2010/11). Pilar is an "average" "middleaged" woman, who lives alone, but has a friend who is a painter (Cândido Ferreira) and seems to want a more intimate relationship with her. A Catholic, and member of a NGO, Pilar shows solidarity with her neighbour Aurora (Laura Soveral) and is cordial with her maid, Santa (Isabel Munoz Cardoso). Santa is also middle-aged, apparently lives alone, is black and is attending a course to learn how to read and write.

In addition to living in the same building and having roughly the same age, Pilar and Santa, seem to share the same imaginary universe: Pilar goes to the cinema where she sees a film about a colonial "intrepid explorer". Santa learns how to read with Robinson Crusoe, the founding work of the colonialist imaginary universe. The links of similarity are very important here because, more than creating a common context, they underline the links of contrast that are established between Santa and Pilar. Given that these characters function via a specular logic, the relationship that we establish between them is symmetrically reversed: Pilar first appears facing the camera, centred in the image, seated. Santa appears, also in the centre of the image, but with her back turned to the camera, standing up. Pilar is white, Santa is black. Pilar prays, Santa smokes. Pilar advises Aurora, Santa prefers to remain silent. Pilar worries about things, Santa shows indifference. In short, it seems that Pilar wants to be a saint (Santa), seeking to be a good Christian in everything she does, while Santa behaves like a true pillar (Pilar) of resistance and stoicism, in face of the abuses of her employer, Aurora ${ }^{3}$.

Santa is culturally categorised by her employer, and in the film she is presented as a passive agent. Curiously, the maid's behaviour indicates complete disregard of Aurora's interpretations of her and which are reflected in the relationship with Pilar. Santa does not need legitimation from either Aurora or Pilar. But Pilar seems to need legitimising approval from the Church, from the NGO where she works, and also from her friends (all

\footnotetext{
${ }^{3}$ In Portuguese the word Santa means saint and the word Pilar means pillar.
} 
of them, except for Santa, tell her that she's a good person) because she is part of the world that creates the discourses. Pilar belongs; Santa stands at the margin.

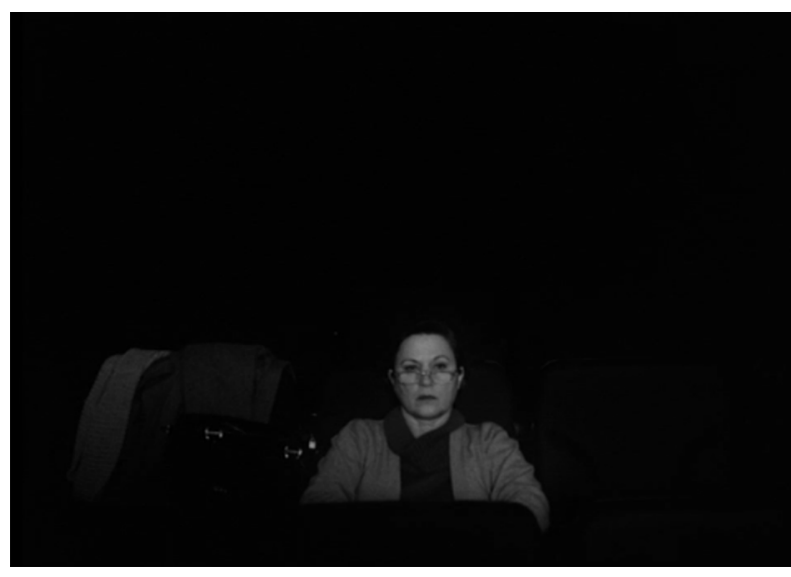

Figure 2: The first time we see Pilar (C) Miguel Gomes

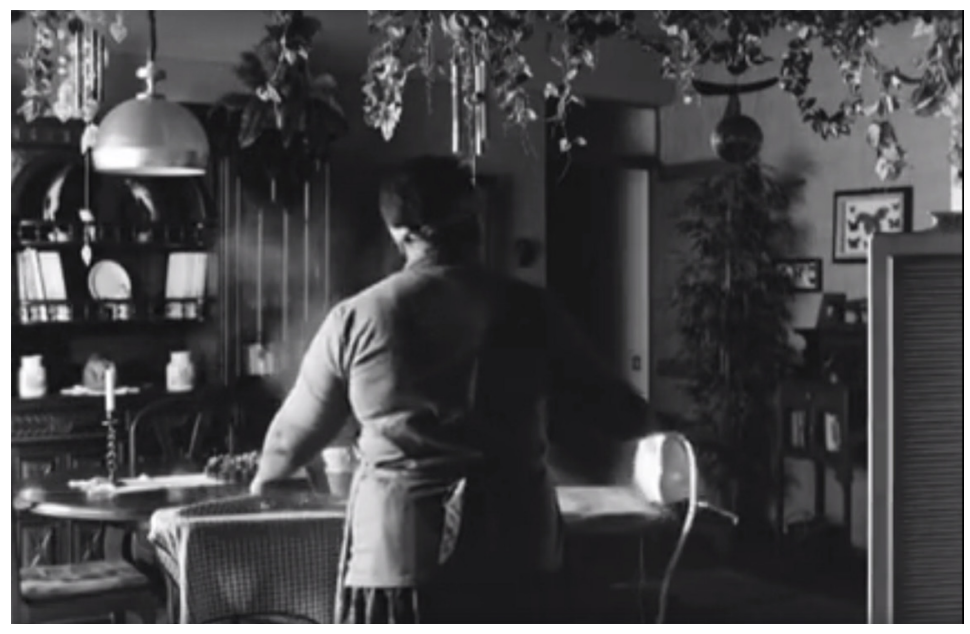

Figure 3: The first time we see Santa (C) Miguel Gomes

Beyond this game of contrasts, that is also constituted as that which Van Leeuwen (2005) would call rhythmic alternation, this relationship by opposition helps define each character. This method of construction of the characters is also a way to construct identity and otherness inside and beyond the film. Santa does not express either opinions or wishes. The character's lines are always related to her duties as Aurora's maid and nurse. This thereby underlines the idea that the African "other" has no voice in contemporary Portugal that, in turn, does not know who the "other" is, what he feels, or thinks. Hence, Pilar distrusts Santa, just as she distrusts everything unknown and that is defined by opposition. Perhaps for the same reasons, Santa cannot trust Pilar: "modern thought is not just binary but a particular kind of binary-producing machine, where binaries become constitutive differences in which the other is defined by its negativity". (Grossberg, 1996, p. 94). Despite coexisting side by side, Pilar and Santa live in radically separate worlds. 
They are, I propose, the real protagonists of the human drama presented by the film, being the only ones that do little or nothing to change the course of events. Regardless of faith, moral values or even the intimate story of each, Santa and Pilar are doomed to live in a Paradise Lost due to other people's sins.

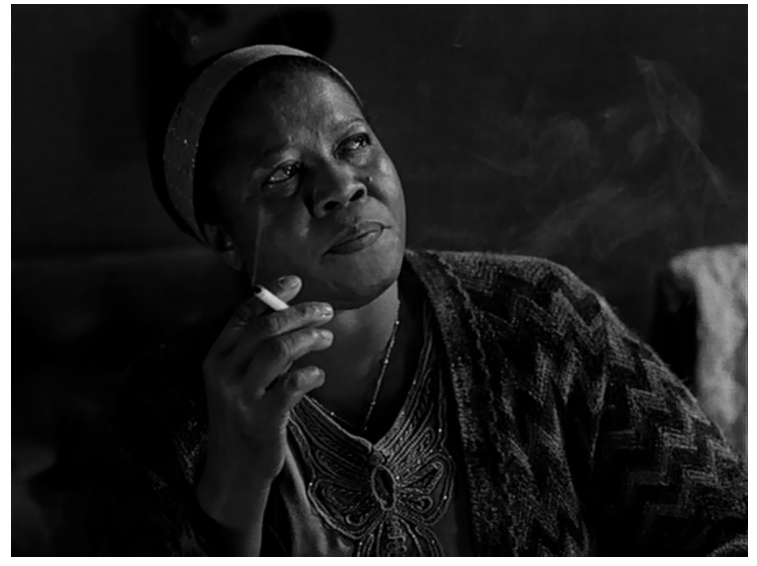

Figure 4: Pilar prays in a vigil (C) Miguel Gomes

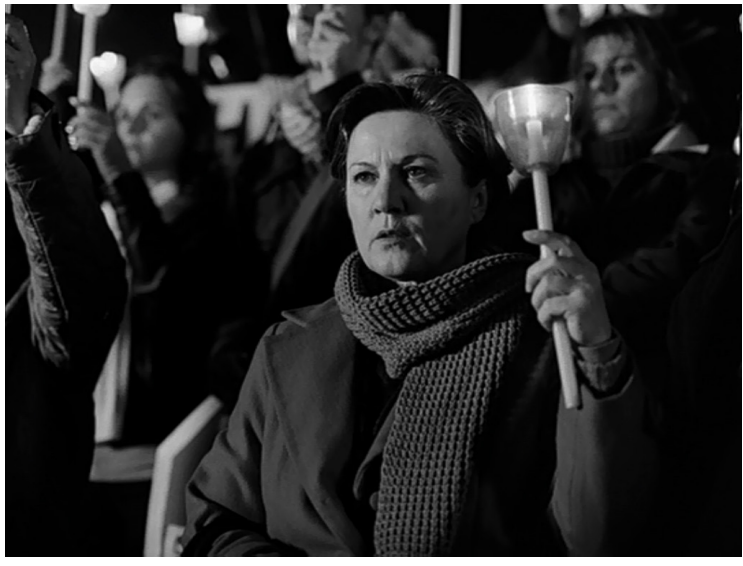

Figure 5: Santa smokes (C) Miguel Gomes

Aurora appears in the centre of the image; behind the image of the Casino (dim, rough), she revolves around the axis constituted by her, encapsulating her. She tells Pilar about a dream which serves as a justification for why she went to gamble in the Casino and lost all her money. We later realise that Aurora was educated in a world that revolved around her and which, in her head, perhaps still does. At the end of this shot, Aurora says: "I'm a fool, because people's lives aren't like dreams".

Considerably older than Pilar and Santa, Aurora provides the bond between these two characters and between their two worlds and paradoxically (in symbolic terms) is the cause of the impossibility of the two getting closer together. She lives in Lisbon, in a relatively modest apartment but cultivates dreams of grandeur. She tries not to lose her glamour. She often goes to the casino and mistreats Santa, her maid, nurse and guardian who, apparently, is paid for by her daughter. Aurora lives embittered, half-crazy, abandoned by her daughter (who lives in Canada) and forgotten by the world. She blames Santa for all her misfortunes.

For Aurora, Santa is the Africa that has come back to take revenge for all the sins she committed there. She says to Pilar:

This black was sent by the horned one ${ }^{4}$ [she puts her forefingers on her forehead to mimic horns] because I'm his prisoner. Santa perpetrates sorceries against all of us, against you too, Pilar, because he is terrible, but he has no power over you. He does against me, because I have blood on my hands.

Santa allows herself small revenges against her mistress. This behaviour is masterfully represented in the silent scene in which, sitting in Aurora's front room, Santa tastes

\footnotetext{
${ }^{4}$ The horned - in Portuguese o cornudo - the one who has horns, meaning the devil.
} 
some prawns that Pilar offered to Aurora, smoking a cigarette at the end of the meal and lying on the couch, reading a juvenile version of Robinson Crusoe. This book is perhaps the first book that Santa reads and Tabu doesn't reveal whether Santa has any reaction to it. The film doesn't show any of Santa's emotions, even when the teacher praises her in a highly condescending manner. As already mentioned, in spite of being a character who is always present in the action, Santa is included as a passive agent in almost the entire first part of the film, but is also excluded by suppression from the emotional discourse.

This first part of the film occurs in a fascist and colonial Lisbon: the action takes place in zones of Lisbon built during the Estado Novo regime (some with the assistance of African immigrant labour). They are: Portela Airport that was built to serve the Exposition of the Portuguese World, in 1940, but was only inaugurated in 1942; Estoril Casino that was built in the 1910 s but underwent a major architectural intervention in the 1960s; The residential zones of the Avenidas Novas and Olivais, wherein the latter was built as a counterpart to the former, designed for underprivileged communities. They are the architectural manifestations of the regime of that time, and have been preserved and inhabited until the present day, but emptied of their dream-based power, that of the Empire. This cartography of the city also illustrates the title of part one. Lisbon is presented to us as a Paradise Lost, a memory of discursive construction that was interrupted, curtailed or simply emptied. Even the Calouste Gulbenkian Foundation, which is a private institution of vital importance for Portuguese art, that wa created as an area of freedom, only appears here in appearance, displaced. Built in the 1960s, this Foundation is only made possible and acquires its importance, through the political, economic, and social context in which it was built and subsists. In Tabu its gardens also represent a space of freedom in an oppressive Lisbon: that of Maia, the young Polish girl who stops staying at Pilar's house.

As with the architectural constructions, the ideological constructions also have deep foundations that influence the way that the social fabric develops. Thus, the behaviour of the characters is marked by formality (sometimes even an awkward stiffness), crystallised in social roles that pertain to another era. The cultural identity of a contemporary citizen is generally considered to be more varied, inconstant, plural, changeable (Bhabha, 1998), but the Lisbon that appears in the film is an isolated city, frozen in time.

Aurora's death, which could serve as an opportunity for Pilar and Santa to come closer together, doesn't achieve this. We can think that, with Aurora's death, the remnants of colonialism have symbolically died. However, colonialism endures as a collective heritage; its consequences are felt in everyday life and in the manner in which identity and otherness are built, and therefore, in social relations. Both, Pilar and Santa, will continue to distrust each other. They will remain side by side, like two perfect strangers, and this possibility illustrates the way that many black people and so many white people live in contemporary Lisbon and Portugal.

Aurora's death is the pretext for the appearance of Gian Lucca Ventura (Henrique Espírito Santo), Aurora's former lover, who tells Pilar and Santa about his life in Africa at the foot of the (imaginary) hill of Tabu, where Aurora lived and inherited a considerable fortune. 


\section{PARADise}

A flashback returns us to Africa - Paradise - and in the second part of the film the behaviour of the white characters (the only characters, because the blacks are merely extras) is completely different. The relationships between the characters and with the space that they inhabit exhibits a freedom that contrasts profoundly with the formalism of the first part of the film. The rigid behaviour, the formality of the relations that characterise present-day Portuguese society, still living in the cold sobriety of the buildings erected during the Estado Novo regime - and therefore where one can still see the relations of power of colonialism, the isolation of the dictatorship, and Christian suffering - are now replaced by a world where apparently there is only one frontier: that which separates blacks from whites. In this manner, an entire discursive heritage, based on the simplification of the ideas of Gilberto Freyre (1998), who depicted Portuguese colonialism as a phenomenon of intense interracial fraternisation (Castelo, 1998), is transversally questioned.

Gilberto Freyre's luso-tropicalism was used during the Estado Novo to help build the idea that Portuguese are not racists and their own particular way of colonialism is, therefore, much better than any other.

In spite of being a concept developed by a sociologist - that could find resistance in the adhesion of the non-academic world - luso-tropicalism, or rather a simplified vulgate of it, was quickly incorporated into the political discourse but also into the common identity-based discourse. (Piçarra, 2015, p. 125)

However, it is not in this simplified version of Gilberto Freyre's theory that Gomes bases the narrative of his film. On the contrary, in the Paradise section of Tabu, Gian Lucca's voice tells us about the story of a group of white friends in Africa, of a treason, and a murder, all this without the blacks and whites ever mixing, although they co-exist.

One of the initial sequences of part two, presents Aurora as a young woman (now played by Ana Moreira), in various activities, almost always surrounded by black servants who clean, or serve her; who she teaches to read, etc. A particularly interesting moment is that where a black child holds a donkey, while Aurora makes a drawing. At the end, we realise that the young woman only drew the animal's snout, as if it never occurred to depict the child holding it.

Gian Lucca (now played by Carlotto Cotta) was Aurora's lover and one of the protagonists of the drama. It is through the narration of this old Italian adventurer that we learn about these young people and the lives that they led. Although the narrative proceeds without making any judgements, other than some against himself, both he and his friends seem to be politically alienated, socially insensitive, idle, practitioners of the most shameless false civic and religious morals. For example, we can see the way that Lucca describes Mario (Manuel Mesquita) a former seminarian and leader of a musical band formed by the men of his social group. 
The women were sensitive to his charm and my friend didn't hide his preference for the natives: one of them later had a child. On the rare occasions that he remembered the boy, he used to go on a Sunday excursion with him.

Also, the (non) relationship between the soundtrack and Africa is revealing. The use of Lonely Wine, by Roy Robinson, or Baby I Love You by the Ramones, makes it clear that the "soundtrack of the lives" of those characters involves nothing African. The music that these young people listen to, and make, is the American and European music of that period, without any African influence and therefore very far removed, once again, from the representations that places the Portuguese colonist in deep cultural communion with the colonised peoples.

It is, however, through the relation between the text and images that the filmmaker underlines the entire political question; while a pathetic love story unravels, he does not shy away from invariably showing black people working. This happens, for example, when, featuring their own voices, we hear the letters exchanged by the lovers:

My dear Aurora,

It is you, my lady, who must forget me, because I'm not, and will never be, more than a despicable wrongdoer. Although I never thought that in the midst of so much vileness, my biggest crime would be that of falling in love [always showing black people working in the field]. It would be a lie, if I denied how much I still think of you. If I told you some of the thoughts running through my head [image of a black man dressed in white, like a sailor, keeping guard on other people working in the background, while one person works in the foreground] childish raptures, insanities and without any kind of future...

Later, a letter from Aurora (the only voice that we hear, beyond that of Gian Lucca) is complemented by images of tea fields, that stretch out into the horizon, where groups of black men are hard at work. Never during these long tracking shots do any black characters stand out. Only a black foreman, dressed in western clothes, is shot in a way that singles him out.

The difference between the emotional distress, the result of an adventurous and idle life, permeated by false morals and vice, and another life of suffering caused by exploitation, by hard work and negation of humanity, is underlined in the film through this kind of contrast between the images and text - in this case, between Gian Lucca's conscious narrative and what he supposedly says unintentionally5. In the images we do see some black people, but they appear as elements of the landscape, trees or hills, always at work.

\footnotetext{
${ }^{5}$ This contrast between text and image can also be interpreted as the contrast between what Gian Lucca says and what Santa and Pilar can imagine. This interpretation would place the imaginary of these two characters even closer and would give them a strong critical awareness before what they are listening to.
} 


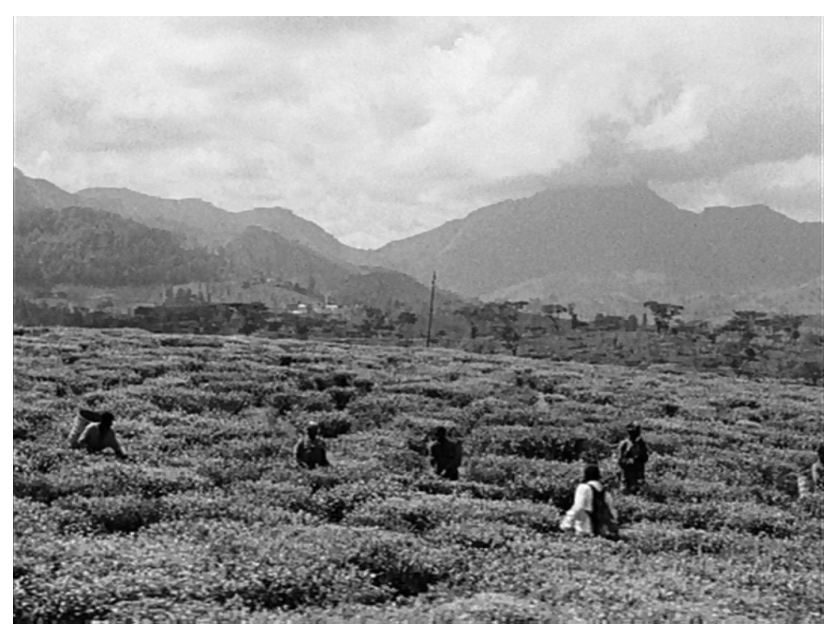

Figure 6: Final tracking shot: fields stretching out into infinity, where black people work while the protagonists exchange love letters

$$
\text { (c) Miguel Gomes }
$$

Black people are almost always excluded by suppression in Gian Lucca's discourse. In other words, they are often present in the actions, but they are not referred to, and, as if highlighting the mentality of the epoch that is being portrayed, we see images that involve them in the action solely as passive agents, wherein they are also culturally and biologically categorised, in an indirect manner, via Gian Lucca's discourse and in a direct manner via the displayed images.

In the only scene in which a black man stands out - and in which Aurora reveals great cruelty - we cannot discern his personality. He is mentioned as a piece of property and appears as a representative of "their" culture, "their" habits, "their" sorceries, and forms part of a dangerous and even disgusting "other" that Aurora can't allow to stay in her house.

Among Aurora's possessions one stood out: the house cook [image of the cook cutting a chicken, dressed in western clothing, but wearing an African necklace]. An elderly man who served her husband's family for decades and whose culinary reputation was extraordinary. As he was also a sorcerer, he had the habit of reading the future in the entrails of the animal he prepared for the masters. One day in October, after the onset of the rains he confided to the maids what the spirits had told him [In the image, through the kitchen's window, black women talking to each other] that the Mistress was pregnant, that she would have an embittered and lonely end. But one of the maids betrayed him and Aurora learned about his prophecies. Furious, she took advantage of the information to sack him, claiming she couldn't abide repugnant and heretic rituals.

In the image we see, through the kitchen window, the cook departing. He carries a broken umbrella (the rainy season had begun) and a small bag of personal belongings. Gian Lucca also says "Time showed that his first prediction was right". It is already 
known, from part one, that time would prove that all the sorcerer's predictions were correct.

Through the words of Ventura, at this point, we see that Aurora had a certain disregard for her husband (Ivo Müller) and for his family. Later, Gomes tries to describe the personality of Aurora's husband, somewhat by opposition to her own personality and that of her friends, for example, fraternisation between the master and his servants when he learned that he was going to become a father. However, once again, the images clarify what the text doesn ' $t$ say: if the differences in treatment are great in this case, the structural differences of the relationship between explorer/exploited seem almost to be non-existent, to the extent that the workers who celebrate the master's happiness also seem to be quite subservient and ragged.

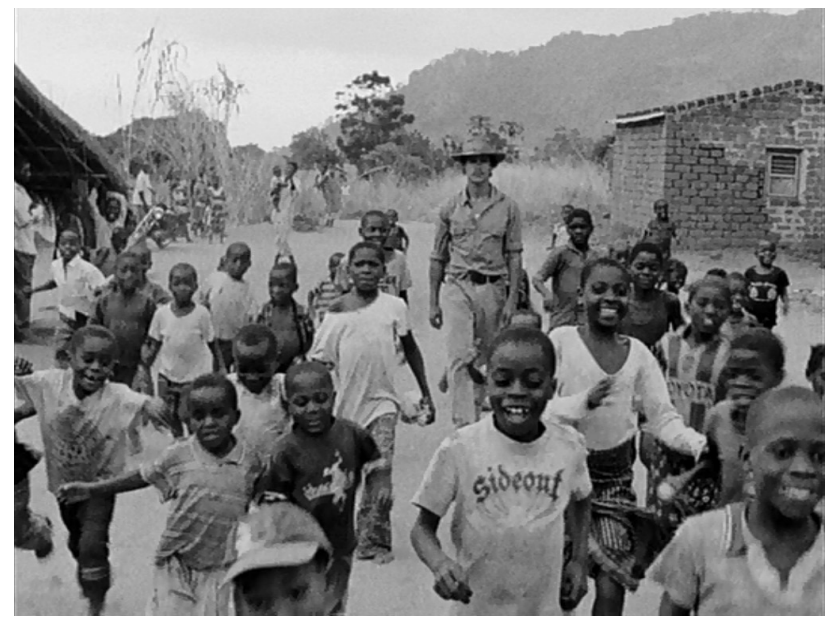

Figure 7: A group of children run freely, while Gian Lucca is left behind (c) Miguel Gomes

Paradise ends with a scene where Gian Lucca, at the centre of the image, is left behind, overshadowed by a group of smiling black children, running towards the camera - wherein once again, we see a large group of children without any single child standing out in particular. We might think that Gomes doesn't resist the temptation to represent Africans as happy and carefree eternal children, who are unable to take care of themselves, wherein such ideas are often found in the common sense discourse (Cabecinhas, 2007). But this image may also suggest hope for the future of the countries that gave decisive steps towards their liberation. In fact, we only see black people from now on and, yes, for the first time, in their villages, conducting the specific tasks of their own culture (identical, once again, to those represented in colonial documentaries), while we hear false news bulletins ${ }^{6}$ on the radio about the war for independence. It's the first time we hear the voice of the African "other" in the film and it sounds, on the one hand, as a lie, and on the other, as ridiculous, given the ideological exaggeration of the construction of the discourse of the news bulletins.

\footnotetext{
${ }^{6}$ The self-proclaimed revolutionary forces claim responsibility for Mario's death, but it was actually Aurora who killed him.
} 


\section{FinAL CONSIDERATIONS}

Tabu is characterised by an aesthetic and political attitude that seeks to create "dissension about ideas, perceptions and fixed concepts, especially related to history, symbolic expression and the identity of a country." (Ferreira, 2014, p. 284). It's a post-colonial film, in the sense that it represents a contemporary reflection on the colonial consequences that the "colonialist mentality" brings today to the Portuguese society. Why do we feel, then, that his film, more than others perhaps, must be "viewed carefully and with an open mind" (Ferreira, 2014, p. 293)?

Tabu presents us with a kind of temporal mise en abyme, in which the present (mentally) contains a past time, which in its turn contains a more remote past. Three spaces correspond to these three times: contemporary Lisbon for the present; the space of Portuguese Africa for the past; and the African jungle, not yet tamed by the colonists, for the more distant past (Prologue). These times and spaces always feature the coexistence of black and white people, Europeans and Africans; civilised (cultivated) and savages (illiterate); masters and servants. In a first reading, we realise that the director filmed the black people as they were often filmed during the colonial era. In this period, the African "other" was for Portuguese people and for Portuguese cinema, first the "indigenous"; later the "black"; and later the "half-caste", or "assimilated" person, through whom the identity of the Portuguese citizen of the colonial empire and finally of the Overseas Provinces $^{7}$ was constructed (Baptista, 2013, p. 147).

Using a multimodal approach towards the film it is possible to identify, however, the semiotic resources that the director used in order to build a discourse about this discourse; either via rhythmic alternation or scenic composition, either through permanent observance of informal connections, either via the relationship that is established between the dialogues/sounds and the actions that accompany them.

Gomes indulges us with a reflection on the discourse of exclusion and on differentiation, which is responsible for (re)constructing and (re)producing otherness, clearly tracing the "other", so that he appears identifiable and paradoxically (in)visible. He becomes rapidly identifiable because he belongs to a group to which characteristics were attributed in order to homogenise all its constituent elements, and that radically separate it from "normal" society and, on the other hand, he appears invisible as a person, as a single individual (Cabecinhas, 2007; Lewin, 1997).

The film seems to accept the existence of a dialectical relationship between identity and otherness (Silva et al., 2000) that, thus, mutually define each other. These are born in social relations, which means that their definition - discursive and linguistic - is subject to vectors of force, to power relations: "identity and difference are never innocent" (Silva et al., 2000, p. 81) because where there is differentiation, there are power relations. Tabu also shows that "the 'units' which identities proclaim are, in fact, constructed within the play of power and exclusion, and are the result, not of a natural and inevitable or primordial totality but of the naturalised, overdetermined process of "closure'" (Hall

7 Overseas Provinces - Províncias Ultramarinas, name given to the colonies, in the last period of the Portuguese colonialism. 
et al., 1996, p. 5). Through the images, the games of contrast between the images and words, the memories that the images conjure up and the relationship between both parts (time periods) of the film, Gomes emphasises the process of social comparison that engenders otherness: differentiation.

Differentiation divides, separates, classifies and normalises, at the same time that it ranks hierarchically. To rank hierarchy often consists of fixing a specific identity as a norm, giving it characteristics that are considered to be positive, in relation to which all other identities will be evaluated negatively (Silva et al., 2000). Thus, difference is constituted as a founding element of the entire classification system that seeks to define who is "identity" and who is the "other", and the negativity of difference is essential in order to be able to affirm the positivity of the identity: "imposing differences means more an affirmation of the unique legitimate identity, that of the dominant group, than the recognition of cultural particularities" (Cuche, 1999, p. 187). With the function of building and rebuilding, producing and reproducing otherness, differentiation defines who is the "other", making him identifiable, predictable, but invisible.

The option to shoot Tabu in black and white ads, especially in part two, a feeling of nostalgia. However, this Paradise, revealed like old photos whose contours already appear to be poorly defined, is a fictitious colony that follows after part one, which takes place in present day Lisbon (2011) that appears in the film to be frozen in time: it is still colonialist, still fascist, still dominated by Catholic morality, either in terms of the way that the characters behave, or by the filming locations chosen (architectural and symbolic spaces).

It is possible to read Tabu as a post-colonial film, however, in terms of "racial" representations, more than a post-colonial object, we are in the presence of a film that requires a post-colonial lens in order to understand it. Traditionally the silencing of the "other" was used to construct the positivity and superiority of the "I", of the "norm", of the "identical". In Tabu, this same silencing emerges as part of the crime, part of the sin that originated the expulsion from Paradise and that now prevents the dream of a freer, more equal, happier society.

During the film, several representations are questioned: the representation of the colonist as a highly responsible worker, entrepreneur, civilising force, generous, "friend of the blacks". The film also questions the representation of the colonised people, showing how this representation was construed, in other words, without the participation of the persons represented. In Tabu, the characters of Paradise Lost, which is a certain presentday Lisbon, apparently doomed, we don't know for how long, experiencing atonement for the "crimes that were committed there", too persistently, consistently and for too long.

\section{FINANCING}

This article is part of a PhD research project in Cultural Studies, whose theme is "Otherness and Identity in postcolonial cinema in Portugal and in Mozambique", funded by the Fundação da Ciência e Tecnologia (Science and Technology Foundation), in the field of Communication Sciences, with the reference SFRH/BD/110044/2015. 
Revision of translation from Portuguese into English financed by COMPETE: POCI01-0145-FEDER-007560 and FCT - Fundação para a Ciência e Tecnologia, within the context of the project: UID/CCl/00736/2013.

\section{VIDEO/FILMOGRAPHY}

Kotek, E. (2012). Miguel Gomes talks "Tabu" At TIFF. Retrieved from https://www.youtube.com/ watch?v=OApKuDY6Dw8

Zona 2 (Producer) \& Gomes, M. (Director). (2013). Tabu. Portugal.

\section{BIBLIOGRAPHIC REFERENCES}

Baptista, M. M. (2013). The works of Sísifo: memories and identities of the Portuguese in Africa according to fiction films of the twentieth century. In R. Cabecinhas \& L. Abadia (Eds.) Narratives and social memory: Theoretical and methodological approaches. (pp. 146 - 58). Braga: CECS. Retrieved from http://www. comunicacao.uminho.pt/cecs/

Bhabha, H. K. (1998). O local da cultura. Belo Horizonte: UFMG.

Cabecinhas, R. (2002). Media, etnocentrismo e estereótipos sociais. In J. A. B. de Miranda \& J. F. da Silveira (Eds.), As Ciências da Comunicação na viragem do século - Livro de atas do I Congresso de Ciências da Comunicação (pp. 407-18). Lisboa: Veja.

Cabecinhas, R. (2007). Preto e branco: A naturalização da discriminação racial. Porto: Campo de Letras.

Castelo, C. (1999). O modo português de estar no mundo. Porto: Afrontamento.

Cuche, D. (1999). A noção de cultura nas ciências sociais. Bauru: EDUSC.

Fairclough, N. (2001). Discurso e mudança social. Brasília: Universidade de Brasília.

Ferreira, C. O. (Ed.) (2014). O Cinema português através dos seus filmes. Lisbon: Edições 70.

Foucault, M. (1997). A ordem do discurso. Lisbon: Relógio d'Água.

Freyre, G. (1998). Casa grande Q a senzala. Rio de Janeiro: Editora Record.

Grossberg, L. (1996). Identity and cultural studies: Is that all there is? In S. Hall Q P. du Gay (Eds.), Questions of cultural identity (pp. 86-105). London: Sage.

Hall, S. \& Gay, P. (Eds.) (1996). Questions of cultural identity. London: Sage.

Lewin, K. (1997). Resolving social conflits \& field theory in social science. Washington: APA.

Matos, P. F. (2006). As cores do império: Representações raciais no império colonial português. Lisbon: Instituto de Ciências Sociais.

Mendes, M. M. (2013). Sobre dois filmes: Tabu de Miguel Gomes e Deste lado da Ressurreição de Joaquim Sapinho. In Escola Superior de Teatro e Cinema (Ed.), Sobre dois filmes: Tabu de Miguel Gomes e Deste lado da ressurreição de Joaquim Sapinho; Entrevista com António Reis e Margarida Cordeiro (1985) (pp. 5-43). Amadora: ESTC. Retrieved from http://repositorio.ipl.pt/handle/10400.21/2719 
Pereira, A. C. \& Cabecinhas, R. (2014). Alteridade e ficção: Representações "raciais” no cinema pós-colonial em Portugal e em Moçambique. In Z. Pinto-Coelho \& N. Zagalo (Eds.), Comunicação e cultura. III Jornadas Doutorais, Ciências da Comunicação e Estudos Culturais (pp. 105-22) Braga: CECS. Retrieved from http://www.lasics.uminho.pt/ojs/index.php/cecs_ebooks/article/view/1952

Piçarra, M. C. (2015). Azuis ultramarinos. Propaganda colonial e censura no cinema do Estado Novo. Lisbon: Edições 70.

Ponzanesi, S. \& Waller M. (2012). Postcolonial cinema studies. New York: Routledge.

Santos, B. S. (2004). Do pós-moderno ao pós-colonial: E para além de um e outro. Conferência de abertura do VIII Congresso Luso-Afro-Brasileiro de Ciências Sociais. Coimbra. Retrieved from http://www.ces.uc.pt/ misc/Do_pos-moderno_ao_pos-colonial.pdf

Silva, T. T. (Ed.) (2000). A produção social da identidade e da diferença. In Identidade e diferença - a perspectiva dos Estudos Culturais, (pp. 74-101). Petrópolis: Vozes.

van Leeuwen, T. (1997). A Representação dos Atores Sociais. In E. Pedro (Ed.), Análise crítica do discurso: Uma perspectiva sociopolítica e funcional (pp. 169-222). Lisboa: Caminho.

van Leeuwen, T. (2005). Introducing social semiotics. London: Routledge.

van Leeuwen, T. (2008). Discourse and practice: New tools for critical discourse analysis. New York: Oxford University Press.

\section{BIOGRAPHICAL NOTE}

Degree in theater by Escola Superior de Teatro e Cinema de Lisboa and Escola Superior de Música e Artes do Espetáculo do Porto. Actress and stage director since 1996 has exerted teaching activity in the secondary and higher education since 2001. Master's degree in Educational Sciences and PHD student in Cultural Studies at the University of Minho, whose main research interests identity / otherness "race", gender and cinematic fiction.

E-mail: Kitty.furtado@gmail.com

CECS - Universidade do Minho

Campus de Gualtar, 4710-057 Braga - Portugal

* Submmited: 09-01-2016

* Accepted: 02-03-2016 